\title{
Preparation of lignin derivatives and their application as protease adsorbents
}

\author{
Run Fang ${ }^{1,2}$, Yin Lin ${ }^{1}$ Xian-Su Cheng ${ }^{* 1}$ \\ ${ }^{1}$ College of Material Science and Engineering, Fuzhou University, Fuzhou, China \\ ${ }^{2}$ Department of Chemistry and Chemical Engineering, Minjiang University, Fuzhou, China; Corresponding author: \\ cxs2222@sina.com
}

Received 1 September 2009; revised 25 September 2009; accepted 27 September 2009.

\begin{abstract}
Synthesis of two lignin derivatives, lignophenol and lignin-aminophenol, were presented in this article. The chemical structure and the functional groups of lignin derivatives were characterized through FT-IR analysis. The immobilization of three proteases (papain, trypsin and pepsin) on lignin and lignin derivatives was carried out using adsorption technique. The influence of contact time and $\mathrm{pH}$ on the enzyme adsorption by different adsorbents was investigated. Furthermore, enzyme activity recovery was also evaluated. Results showed that lignin and lignin derivatives could adsorb proteases effectively and the adsorption capacity of lingophenol and lignin-aminophenol was higher than that of pure lignin. Meanwhile, the activity recovery of papain and pepsin immobilized on lignin derivatives was very high. This phenomenon suggested that there is a supramolecular interaction between enzymes and lignin derivatives which do not inhibit enzyme activity. Therefore, lignophenol and lignin-aminophenol are both promising adsorbents for enzyme immobilization under acid and neutral conditions.
\end{abstract}

Keywords: Lignin Derivative; Papain; Trypsin; Pepsin; Adsorption

\section{INTRODUCTION}

Papain, trypsin and pepsin are all of proteases found in plant and animal cells that break down proteins or peptides by catalyzing the hydrolysis of peptide bonds. These enzymes, after being immobilized, offer several advantages over their free form equivalent. Examples include better stability, possible reuse, greater sensitivity and greater reproducibility of effectiveness. The immobilization technology of enzyme has been playing an important role in biological industry, medicine and clinical diagnosis, chemical analysis, environmental protecttion and energy exploitation. Apart from recycling the biocatalyst, immobilization yields further advantages, such as the easy removal of the biocatalyst from the reaction mixture and thus, simplified product purification. Different immobilization techniques have been developed including covalent coupling [1,2], enzyme crosslinking molecules [3], adsorption on a carrier [4] and the encapsulation in polymeric gels or membranes $[5,6]$.

Support material is a key factor in enzyme immobilization and considerable attention has been paid to the searching for ideal support materials, which may give the best combination of high remaining activity, low cost and friendly to human health and environment. Lignin (EH-lignin) isolated from the residue of enzymatically hydrolyzed cornstalks (a by-product of fuel ethanol industry) is a novel organosolv lignin developed in recent years [7]. Making use of this biomaterial will not only enhance economic benefits of bioindustry but also diminish potential environmental pollutions.

Lignin is a totally renewable aromatic polymer noted for its versatility and applicability in a variety of uses. Since they are safe to human consumption and environment, some lignin derivatives can even been used as food additives which has been permitted by EPA and FDA. Due to the unique isolation procedures, the content of polar functional groups, such as carbonyl, hydroxyl and phenolic hydroxyl, is very high in EH-lignin. This characteristic makes it possible to utilize EH-lignin, after mild modification, as enzyme immobilization supports. Furthermore, the crosslink structure of modified lignin is helpful in improving the chemical and structure stability of support materials. Enzymes immobilized on lignin derivatives are advantageous because of the capability of transferring active compounds to heterogeneous reactions and the easy separation of them from the reaction mixture subsequently.

The adsorption of endotoxin and bromelain on lignin and lignin derivatives has been reported in our previous works $[8,9]$. It has been found that lignin derivatives, 
prepared through phenol or amino modification, are ideal supports for enzyme immobilization with good adsorption capacity and high remaining activity. In this work, we present the synthesis of two lignin derivatives (lignophenol and lignin-aminophenol) and their application as protease adsorbents. The immobilization of three proteases (papain, trypsin and pepsin) on EH-lignin and lignin derivatives was evaluated by measuring the enzyme adsorption capacity and the activity recovery. The influence of contact time and $\mathrm{pH}$ on the enzyme adsorption was discussed in detail.

\section{EXPERIMENTAL}

\subsection{Materials}

EH-lignin was isolated from the residue of enzymatically hydrolyzed cornstalks and purified in laboratory according to the procedures described in literature [7]. Papain, trypsin and pepsin as well as 4-aminophenol and 4-cresol were purchased from Sinopharm Chemical Reagent Co., Ltd, China. All other reagents were of analytical grade.

\subsection{Preparation of Reagents}

The papain, trypsin and pepsin solutions with different $\mathrm{pH}$ were prepared by dissolving a certain amount of solute in $0.1 \mathrm{~mol} / 1$ phosphate buffer, $0.05 \mathrm{~mol} / 1$ Tris- $\mathrm{HCl}$ buffer and $0.05 \mathrm{~mol} / \mathrm{l}$ lactic acid and sodium lactate buffer respectively. Thermo Orion 828 (Orion, U.S.) pH meter was employed in determining $\mathrm{pH}$ values of the solutions.

\subsection{Preparation of Lignophenol and Lignin-Aminophenol}

Lignophenol was prepared by modifying EH-lignin in a two-phase system composed of p-cresol and $72 \%$ sulfuric acid. The preparation procedures and the characteristics of lignophenol were introduced in our previous works [10].

Synthesis of 4-aminophenol modified EH-lignin (lignin-aminophenol) was carried out in a jacketed reactor flask equipped with a stirrer and a reflex condenser. $0.5 \mathrm{~mol} / 1$ 4-aminophenol solution was prepared by adding $3 \mathrm{~g}$ 4-aminophenol into $55 \mathrm{ml}$ distilled water in the reactor and dissolved at $80^{\circ} \mathrm{C} .5 \mathrm{~g}$ EH-lignin and $35 \mathrm{ml}$ glyoxal was then added into this solution with stirring. After $1 \mathrm{~h}$ reaction at $80^{\circ} \mathrm{C}$, the precipitates were filtered, washed with distilled water and ethanol repeatedly and then dried in a vacuum oven at $50^{\circ} \mathrm{C}$ until a constant weight was obtained. Spectrum 2000 FT-IR spectrometer (Perkinelmer, U.S.) was employed in FT-IR analysis of the derivatives.

\subsection{Adsorption of Enzyme on Lignin and Lignin Derivatives}

50mg support material (EH-lignin, lignophenol and lignin-aminophenol) was incubated with $5 \mathrm{ml}$ enzyme solution in a shaker at $25^{\circ} \mathrm{C}$ for a period of time, the initial enzyme concentration $C_{0}$ was varied depending on experiments. At the end of this period, the supernatant was separated by centrifuging at $3000 \mathrm{rev} / \mathrm{min}$ and then diluted with buffer to $25 \mathrm{~mL}$. Meanwhile, the precipitate was collected and vacuum dried for enzyme activity assay. The amount of immobilized enzyme was determined by measuring the concentration of the free enzyme in the supernatant before and after adsorption with Cary50 UV/VIS spectrophotometer (Varian, U.S.). Reference samples were prepared according to identical procedures described above by adding $5 \mathrm{~mL}$ buffer instead of enzyme solutions.

\subsection{Enzyme Activity Assay}

The activities of free enzymes were determined by measuring the tyrosine amount produced by enzymecatalyzed hydrolysis of casein according to Chinese drug standards: papain [11]. One unit of enzyme activity is defined as the amount of enzyme that produces $1 \mu \mathrm{g}$ tyrosine from casein per min at $40^{\circ} \mathrm{C}$. The concentration of tyrosine was determined at $275 \mathrm{~nm}$ using UV/VIS spectrophotometer. The activity of enzymes immobilized on EH-lignin and its derivatives was measured using the same method as above, except that the enzyme solutions were replaced by a given amount of immobilized enzymes.

\section{RESULTS AND DISCUSSIONS}

\subsection{Characteristics of Lignin and Lignin Derivatives}

EH-lignin is a kind of organosolv lignin isolated from the residue of enzymatically hydrolyzed cornstalks. Compared with traditional lignin derivatives, such as lignosulfonate, EH-lignin possesses some valuable characteristics such as high content of functional groups, less impurities and narrow molecular weight distribution [12].

In the 4-cresol concentrated acid system, lignin fractions contact with acid for a short time may give reactive carbocations $\left(\alpha \mathrm{C}^{+}\right)$, which are stabilized quickly by 4 cresol and results in the formation of diphenyl-methane type materials (lignophenol) presented in Figure 1. Preliminary studies show that lignophenol is a kind of cross-linked polymer with lots of phenolic hydroxyl groups [10].

Lignin-aminophenol was prepared by modifying EHlignin with 4-aminophenol, glyoxal act as cross-linking agent. By introducing amino and phenolic hydro- xyl groups into EH-lignin, the enzyme adsorption capacity 
and the molecular structure of lignin- aminophenol were of great difference to that of native EH-lignin. FT-IR spectra of EH-lignin, lignophenol and lignin-aminophenol are presented in Figure 2. It can be found in the spectrum of lignin-aminophenol that, compared with EHlignin, the relative intensity of the adsorption bands at $3200-3600 \mathrm{~cm}^{-1}$ (assigned to $-\mathrm{OH}$ and $-\mathrm{NH}_{2}$ stretching vibration) and $1637 \mathrm{~cm}^{-1}$ (assigned to $\mathrm{N}-\mathrm{H}$ bending vibration) increase significantly while the intensity of other bands remain nearly unchanged. Similar phenomenon can be observed in the spectrum of lignophenol at $3200-3600 \mathrm{~cm}^{-1}$ (assigned to $-\mathrm{OH}$ stretching vibration). Therefore, it can be tell from FT-IR analysis that the content of $-\mathrm{OH}$ on lignophenol and the content of $-\mathrm{OH}$ and $-\mathrm{NH}_{2}$ on lignin-aminophenol have been greatly enhanced after modification.

\subsection{Adsorption of Enzymes on Lignin and Lignin Derivatives}

The influence of contact time $(t)$ and initial $\mathrm{pH}$ of enzyme solution on the adsorption amount of different enzymes on EH-lignin, lignophenol and lignin- aminophenol were studied in this paragraph.

For initial $\mathrm{pH}$ studies, the papain solutions were prepared with phosphate buffer, $\mathrm{pH}$ vary form 5.0 to 8.0; the trypsin solutions were prepared with Tris- $\mathrm{HCl}$ buffer, $\mathrm{pH}$ vary form 7.0 to 9.0 and the pepsin solutions were prepared with lactic acid and sodium lactate buffer, $\mathrm{pH}$ form 2.5 to 5.0. The initial concentration of enzyme was $C_{0}=5.0 \mathrm{mg} / \mathrm{ml}$ and the contact time $t=50 \mathrm{~min}$. For
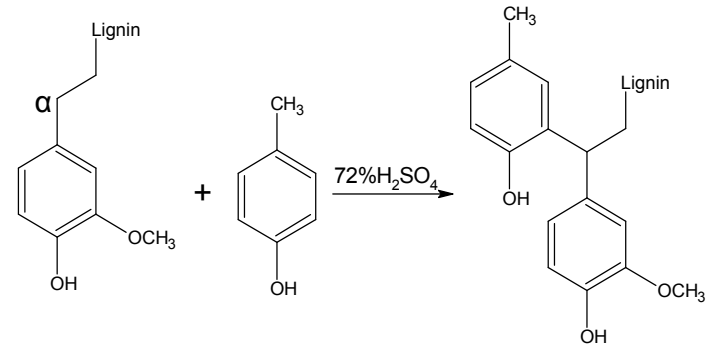

Figure 1. Molecular structure of lignophenol.

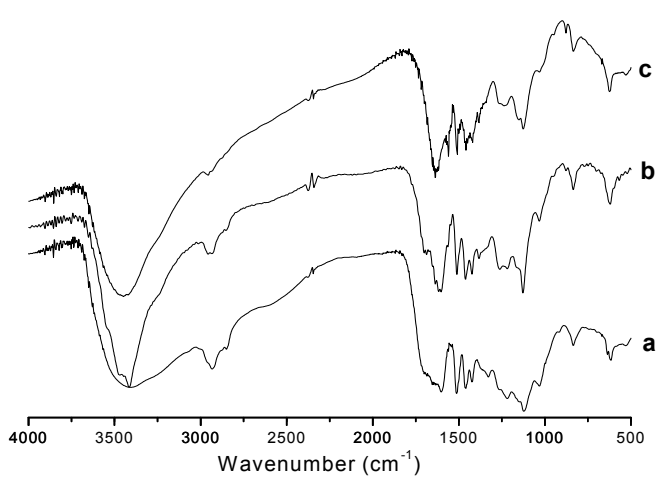

Figure 2. IR spectra of (a) EH-lignin; (b) lignophenol; (c) lignin-aminophenol. contact time studies, the papain solutions were prepared with phosphate buffer $\mathrm{pH} 8.0$, the trypsin solutions were prepared with $0.05 \mathrm{~mol} / \mathrm{L}$ Tris- $\mathrm{HCl}$ buffer $\mathrm{pH} 9.0$ and the pepsin solutions were prepared with $0.05 \mathrm{~mol} / \mathrm{L}$ lactic acid and sodium lactate buffer $\mathrm{pH}$ 3.0. The initial concentration of enzyme was $3.0 \mathrm{mg} / \mathrm{ml}$. All the adsorption experiments were performed at $25^{\circ} \mathrm{C}$ according to procedures mentioned in 2.5 .

\subsubsection{Effect of $\mathrm{pH}$}

The influence of $\mathrm{pH}$ on the adsorption amount of papain, trypsin and pepsin on lignin and lignin derivatives is presented in Figure 3. Figure 3a shows the papain adsorption by different support materials at $\mathrm{pH} 5.0,6.0,7.0$ and 8.0. In these cases, the adsorption of papain increased with increasing $\mathrm{pH}$. The maximum adsorption amount $265 \mathrm{mg} \cdot \mathrm{g}^{-1}$ was reached at $\mathrm{pH} 8.0$ by lignin-aminophenol and $193 \mathrm{mg} \cdot \mathrm{g}^{-1}$ at $\mathrm{pH} 8.0$ by lignophenol. Similarly, the adsorption amount of trypsin on three adsorbents (Figure 3b) increased with the rising of $\mathrm{pH}$ until equilibrium was reached at $\mathrm{pH}$ 8.0-9.0. The maximum adsorption amount $233 \mathrm{mg}^{-1}{ }^{-1}$ was reached at $\mathrm{pH}$ 9.0 by lignin-aminophenol and $171 \mathrm{mg}^{-1} \mathrm{~g}^{-1}$ at $\mathrm{pH} 9.0$ by lignophenol. The variation of adsorption amount of pepsin (Figure 3c) was a little different from that of papain and trypsin. With increasing $\mathrm{pH}$, three peaks of adsorption amount on different adsorbents appeared at $\mathrm{pH} 3.0$ simultaneously. Further increase of $\mathrm{pH}$ led to the decrease of enzyme adsorption amount. The largest adsorption amount was $361 \mathrm{mg} . \mathrm{g}^{-1}$ by lignin-aminophenol and $344 \mathrm{mg} \cdot \mathrm{g}^{-1}$ by lignophenol.

It has been reported that the isoelectric point of papain is $\mathrm{pH} 8.6$ [13]. Meanwhile, we noticed that the adsorption amount of papain on three adsorbents increased with the rising of $\mathrm{pH}$ value, especially when it was close to the isoelectric point of papain. Similarly, the adsorption amount of trypsin and pepsin reached the maxima when the $\mathrm{pH}$ values were closed to their isoelectric point, i.e. about 8.2 and 2.8 respectively $[14,15]$.

This phenomenon may be related to induce polarization that the variation of $\mathrm{pH}$ leads to a corresponding change in the relative abundance of positive and negative sites on the adsorbents and enzymes, thus modulating the strength of the electrostatic interactions between them.

\subsubsection{Effect of Contact Time}

The influence of contact time on the adsorption amount of papain, trypsin and pepsin on three different adsorbents is shown in Figure 4.

It can be seen in Figure 4a that the adsorption of papain by lignin and lignin derivatives was rapid in the first $30 \mathrm{~min}$ and a contact time of only $1 \mathrm{~h}$ was required to attain the equilibrium adsorption. The adsorption amounts of papain on lignophenol and lignin-aminophenol increased up to the highest level i.e. $189 \mathrm{mg} / \mathrm{g}^{-1}$ at 50 min and $259 \mathrm{mg} / \mathrm{g}^{-1}$ respectively at $70 \mathrm{~min}$ respectively, and then remained almost constant. Similar adsorption 


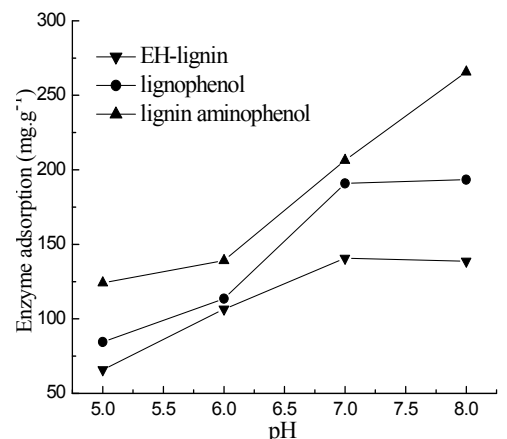

(a)

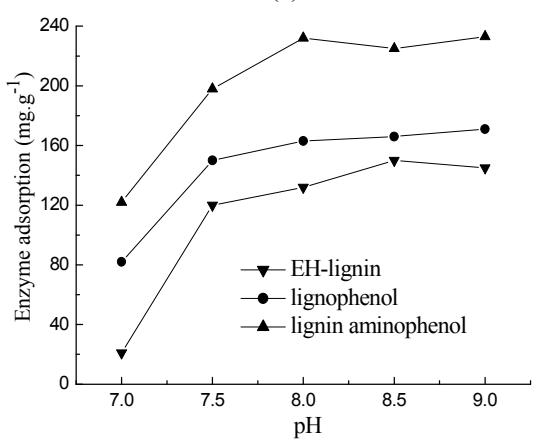

(b)

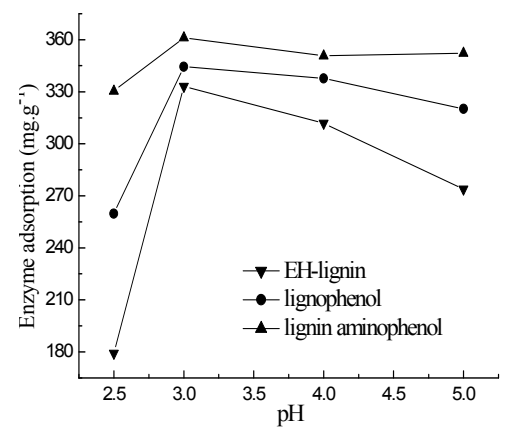

(c)

Figure 3. Influence of initial $\mathrm{pH}$ of enzyme solution on the adsorption amount of three proteases. $C_{o}=5.0 \mathrm{mg} / \mathrm{ml}, t=50 \mathrm{~min}, T=25^{\circ} \mathrm{C}$ (a) papain; (b) trypsin; (c) pepsin.

behavior can be seen in Figure 4b. The adsorption of trypsin reached a maximum value of $158 \mathrm{mg} / \mathrm{g}^{-1}$ by lignophenol and $224 \mathrm{mg} / \mathrm{g}^{-1}$ by lignin-aminophenol at $50 \mathrm{~min}$. The adsorption of pepsin (Figure 4c) increased steadily with extending contact time and the highest adsorption amount was $211 \mathrm{mg} / \mathrm{g}^{-1}$ at $70 \mathrm{~min}$ by lignophenol and $351 \mathrm{mg} / \mathrm{g}^{-1}$ at $70 \mathrm{~min}$ by lignin-aminophenol. In all these studies, the sequence of enzyme adsorption amount goes as follows: lignin-aminophenol $>$ lignophenol $>$ EH-lignin.

It can be found from Figure 3 and Figure 4 that the adsorption amount of pepsin on lignin derivatives is higher than that of papain and trypsin, which may indicated stronger interactions between lignin derivatives and pepsin. The features of their chemical structure and

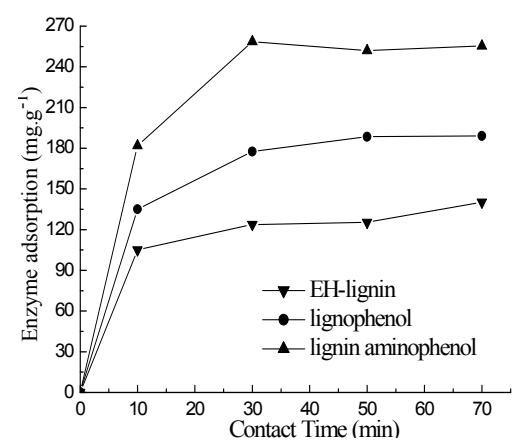

(a)

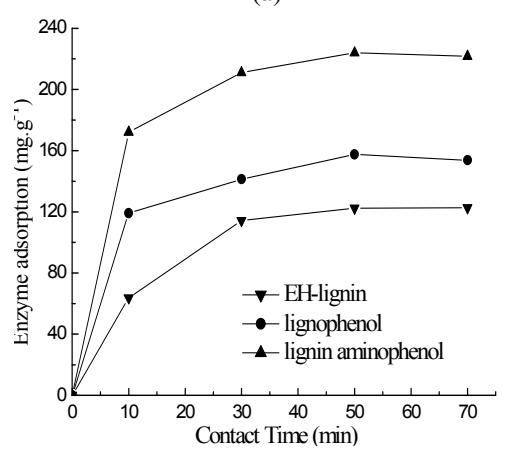

(b)

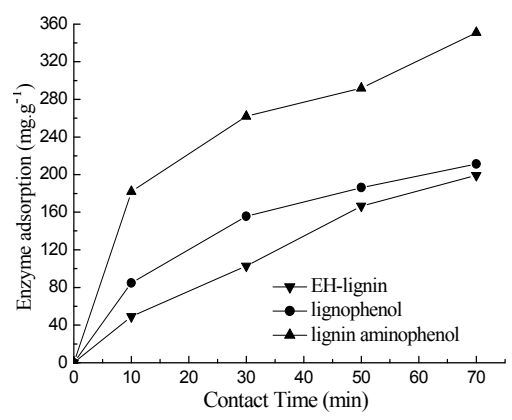

(c)

Figure 4. Influence of contact time on the adsorption amount of three proteases. $C_{o}=3.0 \mathrm{mg} / \mathrm{ml}, T=25^{\circ} \mathrm{C}$ (a) papain at $\mathrm{pH} 8$; (b) trypsin at $\mathrm{pH} 9$; (c) pepsin at $\mathrm{pH} 3$.

the higher adsorption capacity of lignin derivatives under acid condition are both possible reasons.

Despite the variation of contact time and initial $\mathrm{pH}$, the sequence of enzyme adsorption amount of three support materials goes unchanged as follows: lignin-aminophenol $>$ lignophenol $>$ EH-lignin. Therefore, it is clear that the enzyme adsorption capacity of lignin derivatives increase significantly after modification. On considering the chemical structure, as has been mentioned in 3.1, the content of phenolic hydroxyl groups was increased in lignophenol and both of amino and phenolic hydroxyl groups were enriched in lignin-aminophenol after modification. These polar functional groups, which may interact with amino and carboxyl groups on enzymes, will favor the enzyme adsorp- 
Table1. The activities of three proteases before and after adsorption.

\begin{tabular}{ccccc}
\hline Proteases & Adsorbent & $\begin{array}{c}\text { Before adsorption } \\
/ \mathrm{U}^{-1} \mathrm{mg}^{-1}\end{array}$ & $\begin{array}{c}\text { After adsorption } \\
/ \mathrm{U}^{-1} \mathrm{mg}^{-1}\end{array}$ & $\begin{array}{c}\text { Activity recovery } \\
/ \%\end{array}$ \\
\hline \multirow{3}{*}{ Papain } & EH-lignin & $1.68 \times 10^{3}$ & $0.19 \times 10^{3}$ & 11.3 \\
& lignophenol & $1.16 \times 10^{3}$ & $0.65 \times 10^{3}$ & 55.7 \\
\multirow{3}{*}{ Trypsin } & lignin-aminophenol & $0.96 \times 10^{3}$ & $0.51 \times 10^{3}$ & 53.1 \\
& EH-lignin & $6.98 \times 10^{3}$ & $0.52 \times 10^{3}$ & 7.5 \\
& lignophenol & $1.37 \times 10^{4}$ & $0.13 \times 10^{4}$ & 9.6 \\
Pepsin & lignin-aminophenol & $1.42 \times 10^{4}$ & $0.31 \times 10^{4}$ & 21.5 \\
& EH-lignin & $5.15 \times 10^{3}$ & $0.65 \times 10^{3}$ & 12.6 \\
& lignophenol & $6.62 \times 10^{3}$ & $5.00 \times 10^{3}$ & 75.5 \\
\hline
\end{tabular}

tion through the formation of hydrogen bonding $[16,17]$. Furthermore, due to their hydrophilic characteristic, the introduction of amino and hydroxyl groups into support materials will lead to a better contact between lignin derivatives and free enzymes suspended in aqueous solution and thus, a larger quantity of enzymes become linked.

\subsection{Remaining Activity Analysis}

The remaining activities of immobilized enzymes were evaluated and the results were compared to that of free enzymes. Since we have already investigated the influence of adsorption time and $\mathrm{pH}$ value on enzyme adsorption, the optimum conditions mentioned in 3.2.1 were used in the activity recovery experiments. The activities of free and immobilized enzymes were determined following the method mentioned in 2.6.

Table 1 shows the activities of papain, trypsin and pepsin before and after adsorption by lignin and lignin derivatives. It can be seen in Table 1 that the activities recovery of all three proteases immobilized on lignophenol and lignin-aminophenol is higher than that of proteases adsorbed by native EH-lignin. Compared with EH-lignin, the larger enzyme adsorption capacity of lingophenol and lignin-aminophenol is an important factor that leads to higher activity recovery which has been discussed in 3.2. Another factor, the interaction between enzymes and support materials, also makes a contribution to this outcome. Enzyme immobilization can causes changes in the tertiary structure of the protein which in turn may influence the activity under specific conditions. Therefore, the activity decrease after immobilization can be explained by the intermolecular interaction between enzymes and support materials that change the conformation of the enzymes. The high activity recovery of papain and pepsin adsorbed on lignophenol and lignin-aminophenol indicates a supra-molecular interaction between enzymes and lignin derivatives which has little side-effect on the activity of the enzymes. Modified EHlignin is a high molecular composed of phenylpropane skeleton as the hydrophobic group and amino, hydroxyl and carboxyl as the hydrophilic groups. Therefore, the supramolecular interaction may be a combination of hy- drogen bonding and hydro- phobic interaction [18].

Another phenomenon that deserves our attention is the significant difference of the activity recovery between three enzymes adsorbed on the same adsorbent. Despite the variation of support materials, the sequence of activity recovery of three enzymes goes unchanged as follows: pepsin $>$ papain $>$ trypsin. The variation of adsorption amount of three enzymes is a factor that will affect the activity recovery. However, as was shown in 3.2, the adsorption amount of different enzymes on the same support material do not differ a great deal, which means that other influencing factors should also be taken into account.

From the standpoint of the physical characteristics, this phenomenon may be ascribed to the influence of $\mathrm{pH}$ on the dissolution of lignin and lignin derivatives in aqueous solutions. It has been pointed out in some studies that as the $\mathrm{pH}$ of the solution increases, the dissolvability of lignin and lignin derivatives will increase simultaneously [19]. It was also found in our research that when the buffer turned to alkaline, the dissolvability of lignin and lignin derivatives increased rapidly. The adsorption of pepsin, papain and trypsin was carried out under the optimum conditions at $\mathrm{pH} 3.0,8.0$ and 9.0, respectively. The dissolution of support materials under alkaline condition decreased the stability and the yield of immobilized enzymes, which in turn reduced the activity recovery of trypsin remarkably. These analyses indicate that lignin and lignin derivatives are more suitable for papain and pepsin immobilization under acid or neutral conditions.

\section{CONCLUSIONS}

The preparation and characteristics of two lignin derivatives, lignophenol and lignin-aminophenol, was presented in this article. Compared with native lignin, the content of amino and phenolic hydroxyl groups was greatly enhanced after modification.

The results received from adsorption experiments show that three proteases (papain, trypsin and pepsin) can be adsorbed by lignin and lignin derivatives effectively. The adsorption capacity was affected by contact 
time and $\mathrm{pH}$ depending on the feature of enzymes. Despite the variation of enzymes, the sequence of enzyme adsorption capacity goes as follows: lignin-aminophenol $>$ lignophenol $>$ EH-lignin, which is attributed to the enrichment of polar functional groups, such as $-\mathrm{OH}$ and $-\mathrm{NH}_{2}$, in lignin derivatives after modification.

The activity recovery of pepsin and papain immobilized on lignin derivatives under acid and neutral conditions was very high which indicates a combination of hydrogen bonding and hydrophobic interaction between enzymes and lignin derivatives. These intermolecular interactions greatly enhance enzyme adsorption and hardly inhibit enzyme activity. Therefore, lignophenol and lignin-aminophenol are promising support materials for enzyme immobilization under acid and neutral conditions.

\section{ACKNOWLEDGEMENT}

This paper has received support from the fund of State Key Laboratory of Guangzhou Institute of Chemistry, Chinese Academy of Science (LCLC-2004-158).

\section{REFERENCES}

[1] F. Hildebrand and S. Lutz, (2006) Immobilization of alcohol dehydrogenase from Lactobacillus brevis and its application in a plugflow reactor. Tetrahedron Asymmetry, 17, 3219-3225.

[2] C. Mateo, O. Abian, L. R. Fernandez, and J. M. Guisan, (2000) Increase in conformational stability of enzymes immobilized on epoxy-activated supports by favoring additional multipoint covalent attachment. Enzyme Microb. Technol., 26, 509-515.

[3] R. Schoevaart, M. W. Wolbers, M. Golubovic et al., (2004) Preparation, optimization and structures of cross-linked enzyme aggregates (CLEAs). Biotechnol. Bioeng., 87, 754-762.

[4] R. A. Sheldon, R. Schoevaart, and L. M. Van Langen, (2005) Cross-linked enzyme aggregates (CLEAs): A novel and versatile method for enzyme immobilization. Biocatal. Biotransform., 23, 141-147.

[5] A. C. Pierre, (2004)The sol-gel encapsulation of enzymes. Biocatal. Biotransform., 22, 145-170.

[6] L. Veum, U. Hanefeld, and A. Pierre, (2004) The first encapsulation of hydroxynitrile lyase from Hevea brasil- iensis in a sol-gel matrix. Tetrahedron, 60, 10419-10425.

[7] X. S. Cheng and X. L. Liu, (2006) Separation of lignin from cornstalks residue by enzymatic hydrolysis and its properties. Morden Chemical Industry, Supplement, 26 99-102.

[8] X. H. Zhang, X. S. Cheng, and J. Tang. (2006) Adsorption of bromelain with HBS lignin and its derivatives. The Chinese Journal of Process Engineering, 6, 87-90.

[9] Y. Q. Jin and X. S. Cheng, (2006) Study on the adsorption of endotoxin by HBS lignin and its derivatives. Journal of Xi'an University of Engineering Science and Technology, 20, 723-726.

[10] M. J. Li and X. S. Cheng, (2004) Research on the adsorption of endotoxin by lignophenol. Journal of Cellulose Science and Technology, 12, 1-6.

[11] Y. X. Luo, (2000) Studies on the determination of enzymatic active for papain. Chinese Pharmaceutical Journal, 35, 556-558.

[12] R. Fang, X. S. Cheng., J. Fu., and Z. B. Zheng, (2009) Research on the graft copolymerization of EH-lignin with acrylamide. Natural Science, 1, 17-22.

[13] S. Solis, J. Paniagua, J. C. Martınez, and M. Asomoza, (2006) Immobilization of papain on mesoporous silica: pH effect. J. Sol-Gel Sci. Technol., 37, 125-127.

[14] L. Qiao and Y. Liu, (2008) A nanoporous reactor for efficient proteolysis. Chem. Eur. J., 14, 151-157.

[15] M. Casas1 and J. Miñones1, (1992) Effect of polymerized silicic acid on mixed lipid-protein monolayers used as cell-membrane models II pepsin-sphingomyelin films. Colloid. Polym. Sci., 270, 485-491.

[16] S. Dumitriu, P. Magny, D. Montane, P. F. Vidal, and E. Chornet, (1994) Polyionic hydrogels obtained by complexation between xanthan and chitosan: their properties as supports for enzyme immobilization. J. Bioact. Compat. Polym., 9, 184-209.

[17] N. Dizge, C. Aydiner, E. Demirbas, M. Kobya, and S. Kara, (2008) Adsorption of reactive dyes from aqueous solutions by fly ash: Kinetic and equilibrium studies. J. Hazard. Mater., 150, 737-746.

[18] B. Al-Duri and Y. P. Yong, (2000) Lipase immobilisation: An equilibrium study of lipases immobilised on hydrophobic and hydrophilic/hydrophobic supports. Biochem. Eng. J., 4, 207-215.

[19] P. Kauper, (2004) From production to product Part 1: Solution states of alkaline bagasse lignin solution. Industrial Crops and Products, 20, 151-157. 